\title{
Making Sense of Murder: The Reality versus the Realness of Gang Homicides in Two Contexts
}

\author{
Marta-Marika Urbanik ${ }^{1, *}$ and Robert A. Roks ${ }^{2}$ \\ 1 Department of Sociology, University of Alberta, Edmonton, AB T6G 2H4, Canada \\ 2 Erasmus School of Law, Erasmus University Rotterdam, 3062 PA Rotterdam, The Netherlands; \\ roks@law.eur.nl \\ * Correspondence: urbanik@ualberta.ca
}

check for updates

Citation: Urbanik, Marta-Marika, and Robert A. Roks. 2021. Making Sense of Murder: The Reality versus the Realness of Gang Homicides in Two Contexts. Social Sciences 10: 17. https://doi.org/10.3390/socsci10010017

Received: 8 December 2020

Accepted: 6 January 2021

Published: 12 January 2021

Publisher's Note: MDPI stays neutral with regard to jurisdictional clai$\mathrm{ms}$ in published maps and institutional affiliations.

Copyright: $(\odot 2021$ by the authors. Licensee MDPI, Basel, Switzerland. This article is an open access article distributed under the terms and conditions of the Creative Commons Attribution (CC BY) license (https:// creativecommons.org/licenses/by/ $4.0 /)$.

\begin{abstract}
Despite the proliferation of research examining gang violence, little is known about how gang members experience, make sense of, and respond to peer fatalities. Drawing from two ethnographies in the Netherlands and Canada, this paper interrogates how gang members experience their affiliates' murder in different street milieus. We describe how gang members in both studies made sense of and navigated their affiliates' murder(s) by conducting pseudohomicide investigations, being hypervigilant, and attributing blameworthiness to the victim. We then demonstrate that while the Netherland's milder street culture amplifies the significance of homicide, signals the authenticity of gang life, and reaffirms or tests group commitment, frequent and normalized gun violence in Canada has desensitized gang-involved men to murder, created a communal and perpetual state of insecurity, and eroded group cohesion. Lastly, we compare the 'realness' of gang homicide in The Hague with the 'reality' of lethal violence in Toronto, drawing attention to the importance of the 'local' in making sense of murder and contrasting participants' narratives of interpretation.
\end{abstract}

Keywords: gang homicide; comparative research; ethnography; gang violence

\section{Introduction}

Scholars have argued that violence is fundamental to gang life (Klein and Maxson 1989), "so that membership may have a seductively glorious, rather than mundane, indifferent, significance" (Katz 1988, p. 128). The epitome of gang violence is gang homicide, which many academics, police officials, and policy markers consider a unique and distinct type of murder $^{1}$ (Maxson et al. 1985; Maxson and Klein 1996; Maxson 1999). Despite academic, political, and public preoccupation with gang homicides, questions remain about how to define, classify, measure, and study these murders. For example, while some classifications include homicides that are allegedly gang related (where the victim and/or offender are gang members), others necessitate the homicide be motivated by gang functions (for the explicit benefit of the group) (Maxson and Klein 1990, 1996). Scholars also disagree about the necessary motivations for gang homicides, which can be further delineated by expressive (signaling gang power), instrumental (i.e., protecting gang turf) motifs, or both (Decker 1996; Decker and Pyrooz 2013). Importantly, data on 'gangs' and, by extension, on 'gang homicides' are predominantly police generated, and can therefore be riddled with methodological limitations ${ }^{2}$ (see Esbensen et al. 2001; Skogan 1974). These distinctions and data are consequential as they affect how we quantify gang homicides (and therefore fashion

1 Gang homicides are more likely to include multiple offenders, to occur in public settings, to have different spatial characteristics, to involve younger persons, and to involve strangers than nongang incidents (Curry and Spergel 1988; Decker and Curry 2002; Howell 1999; Maxson et al. 1985; Pizarro and McGloin 2006; Pyrooz 2012).

2 Criminologists disagree on this. For example, Decker and Pyrooz (2010, p. 370) argue "contrary to many claims, police reports of gang crime are not fraught with measurement error so as to be unsuitable for meaningful analysis". 
policies/responses), how well our classifications resemble the realities of gang homicide (including motivations), and how we understand the micro processes of gang homicide.

Though no robust predictors of gang homicide exist, several factors can propel its occurrence. Locality can be central to inciting and shaping gang violence, given many gangs' commitments to specific blocks or territories (Aldridge et al. 2011; Brotherton and Barrios 2004; Spergel 1984). Often, gang turf and territory is located within the neighbourhoods in which gangs form and operate, with neighbourhoods providing the sole or primary space for income generation, particularly in relation to drug trafficking (Hagedorn 1994; Papachristos et al. 2013). Therefore, gang violence, including lethal violence, is often related to 'defending' a neighbourhood, showing 'love' for the community, and competition over territory, status, resources, and drug markets (Brotherton and Barrios 2004; Decker 1996; Densley 2012; Hagedorn and Macon 1988; Maxson 1999; Rodgers 2002; Vargas 2014). Given that drug trafficking is a central illegal enterprise for many gangs and drug trafficking escalates risks of victimization and violent offending, gang homicides are often connected to the drug trade (Adams and Pizarro 2014; Blumstein 1995; Curtis 2003; Densley 2014, p. 52). Moreover, the illegality of drug trafficking prevents traffickers from relying upon prosocial governance institutions to facilitate exchange and provide redress for disputes (see Skarbek 2011), necessitating that they take matters into their own hands, sometimes via lethal violence (Adams and Pizarro 2014).

Gang homicide — similar to gang violence more broadly—is not randomly distributed across physical space, but often ensues in gang "hot spots," frequently located in/near marginalized communities characterized by concentrated poverty and where formal social control actors are absent or inadequate (Bursik and Grasmick 1993; Curry and Spergel 1988; Kubrin and Wadsworth 2003; Mares 2010; Papachristos and Kirk 2006; Pizarro and McGloin 2006; Rosenfeld et al. 1999). In addition to ecological and neighbourhood conditions, other factors affect gang violence, including network processes such as a history of conflict and reciprocity of violence. It is therefore unsurprising that gang violence may be more pronounced in areas where competing gangs share an adjacent turf (Papachristos et al. 2013). Further, in such areas, victims/witnesses may be unwilling to cooperate with law enforcement due to distrust in police and strained police-community relationships, an adherence to "street codes" (Anderson 1999) which privilege street justice over police interventions, and/or due to intimidation and silencing (Miethe and McCorkle 2002). This can mask the prevalence and nature of gang violence from neighbourhood 'outsiders' (such as police) and can make preventing, investigating, and prosecuting gang homicides exceptionally difficult. Gang violence/homicide prosecutions can be further complicated by other elements, including multiple victims/offenders, challenges in establishing gang membership in court, and proving the violence was 'gang motivated'. In response, some jurisdictions in the United States have created dedicated gang units and specialized prosecutions to aid the capture and prosecution of those suspected to be involved in gang violence (see Pyrooz et al. 2011; Miethe and McCorkle 2002).

What is particularly notable about gang homicide is its often cyclical and reciprocal nature. Much gang conflict is therefore both a consequence of and precursor to gang violence (Decker 1996). Retaliatory homicides are often connected to and/or direct products of operative "street codes" which, in addition to discouraging cooperation with law enforcement mandate that 'disrespect' is met with violence or it may propel additional victimization $^{3}$ (Anderson 1999; Kubrin and Weitzer 2003, p. 158). As such, retaliatory violence can be a response to competition, an effort to incite social control, to seek "street justice", and to hamper future victimization (Jacobs and Wright 2006; Kubrin and Weitzer 2003; Maxson 1999). The extent to which gangs retaliate for affiliate homicides is unclear; one study found that $37 \%$ of homicides in Chicago amongst organized street gangs were reciprocated (Papachristos 2009). However, some scholars posit gang retaliations are not always

3 See (Urbanik et al. 2017) for a discussion of how street codes can also limit violence. 
targeted at the provoking group but may entail "generalized reciprocity," where the performative aspect of retaliation is directed against a different gang (Lewis and Papachristos 2020).

Recently, gang scholars have become particularly attuned to examining whether and how technology affects gang violence and/or homicide. Though Miller (1975) seminal work on gang violence examined how technological advances such as cars and handguns may have driven the popularity of drive-by shootings, contemporary research has shifted its gaze to the expansion of the Internet and social media. Scholars studying social media and criminally-involved groups have begun to examine the role that social may play in inciting or repelling gang violence and homicide (see Urbanik et al. 2020 for a review).

\section{Current Study}

The proliferation of studies on gang violence has illuminated many facets of this phenomena. However, the bulk of research on gang homicides has examined the emergence of gang violence and its consequences, including retaliation. Consequently, we know little about the residual effects of gang homicide, particularly how they affect surviving gang members and their respective groups. In this paper, we examine how gang murders affect affiliates, focusing on how they experience, make sense of, and to respond to peer fatality. By drawing from ethnographic research in two countries- the Netherlands and Canada-we unmask how street cultures and milieu's affect experiences of gang homicides and respond to calls for comparative and multisite gang research (Klein 2005). We first describe our field sites and the role of gang homicide in our respective studies. ${ }^{4}$ Second, we highlight the commonalities in how gang members make sense of peer murder and discuss the divergent residual effects of these instances. We then center 'the local' (Fine 2010) in documenting how participants' varying local contexts and lived realities impacted how they perceived, experienced, and responded to peer fatality.

\section{Study A: The Forgotten Village, The Hague (The Netherlands)}

Between 2011 and 2013, Roks conducted fieldwork in a small neighbourhood-known as the Forgotten Village-in the city of The Hague, Netherlands, which served as the home base of the Dutch Crips since the late 1980s, who refer to it as their "h200d" (Roks 2017b). Whilst Roks conducted semi-structured interviews, informal conversations, and ethnographic observation with many local residents and stakeholders, he spent most of his time with current and former members of the Dutch Crips. At the onset of the research, the Dutch Rollin 200 Crips consisted of some 50 members (15-40 years old), predominantly of Surinamese and Antillean background. Local and national media have heavily documented the Dutch Crips, including with a 90 min documentary, titled 'Strapped 'N Strong' (Van der Valk 2009). In media interviews, Crips members have consistently referenced their familiarity and experiences with violence and murder and their propensity to use violence when necessary. For example, during one interview with the Dutch magazine Panorama, Raymond—the gang's leader-expressed: "If I want you dead tomorrow, then you'll be dead tomorrow. If I want you to die in one year, you'll be dead in a year" (Viering 1994, p. 41).

Although violence was central to the Dutch Crips' presentation of self in the media, actual levels of (gang) violence in the Netherlands are low, consistent with many other European nations. An analysis of gangs in different countries by Klein et al. (2006, p. 41) indicates that both the patterns of violent behaviour and the levels of violence of European gangs are less serious than in the United States. Klein et al. (2006) attribute these differences to the nature of gangs in Europe, the lower prevalence of firearms, and lesser levels of gang territoriality. In the Dutch context, Ganpat and Liem (2012, p. 329) show that between 1992 and 2009, 223 persons were murdered annually on average, usually precipitated by arguments and domestic disputes. 'Criminal' homicides comprised $12 \%$ of all cases, with incidents varying from "drug addicts killing one another, drug users who killed dealers, and dealers who killed one another during a bad deal" (Ganpat and Liem 2012, p. 333),

\footnotetext{
4 For an extensive overview of both ethnographies, see (Urbanik and Roks 2020).
} 
though none were classified as gang related. The Netherlands' homicide rate has been declining since 2009, with 119 murders in 2018 (CBS 2020), 34 of which were due to gun violence, and an addition 577 incidents involved firearms (RTL Nieuws 2020).

During Roks's fieldwork, one of his participants was murdered. In the late hours of Sunday, August 19th, 2012, Quincy "Sin" Soetosenojo ${ }^{5}$ was shot several times at close range in his hometown of Amsterdam. He succumbed to his injuries and passed away in the hospital later that night. The murder remains unsolved, making it impossible to assess whether this incident could be classified as a gang homicide. Sin's murder was one of 157 murders in 2012, translating into a homicide rate of 0.94 per 100,000 inhabitants (CBS 2017).

\section{Study B: Regent Park, Toronto (Canada)}

Urbanik's research is situated in a neighbourhood just east of Toronto's downtown core, Regent Park. Until its ongoing revitalization, Regent Park was Canada's oldest and largest social housing project, and the neighbourhood amassed a notorious reputation as a space of concentrated, racialized poverty and violence. Between 2013 and 2018, Urbanik conducted ethnographic observation and interviews in the neighbourhood. She spent most of her time "deep hanging out" (Geertz 1998) with approximately 25 ganginvolved men, who loosely belonged to two neighbourhood gangs, The Rich Riderz and The Young Soldiers (see Urbanik 2018). ${ }^{6}$ Despite engaging in several aspects of "gang life" including repping, drug trafficking, turf wars, robberies, gun violence, and gang homicides, these groups were more fluid and loosely organized than larger and more traditional gangs, and had fewer expectations about group commitments. Gun and gang violence are an unfortunate lived reality for many Regent Parkers, and for Urbanik's participants in particular, all of whom reported losing friends, affiliates and family members to gun violence. During the study, many of Urbanik's participants were shot (at) and several were killed.

Similar to the Netherlands, Canada's homicide rate pales in comparison to that of the United States, in part due to stricter gun control. In 2018, Canada reported 651 homicides, and a homicide rate of 1.76 per 100,000 inhabitants. Approximately one-quarter of homicides were classified as "gang related," $83 \%$ of which involved a firearm (Statistics Canada 2019). Toronto-Canada's most populous census metropolitan area (CMA)—reported the most homicides of all CMAs, with 142 victims, a $53 \%$ increase $^{7}$ from the year prior, and a record number since data collection began (Statistics Canada 2019). Thirty-six of these homicides were classified as "gang related". Gun violence is also a growing concern, with many Torontonians-including the former Police Chief-blaming gangs for the shootings (Global News 2019) and news media characterizing the City's gun violence as "civil war" (Warmington 2020). Much of this violence is related to inter-neighbourhood 'beefs', which are particularly common amongst Toronto's social housing projects (see also Berardi 2018).

\section{Making Sense of Murder}

Despite notable differences in street and gang milieus and the frequency of gang homicide across our field sites, our findings unmask several commonalities in how gang members experienced and responded to peer fatality. We first describe how gang members in both studies tried to make sense of and navigate their affiliates' murder by conducting pseudo-investigations, being hypervigilant, and attributing blameworthiness to the victim.

\section{"What happened, and who did it?": Pseudo-Investigations}

Three days after Sin was shot and killed, Roks met with several Crips members who spent most of the evening discussing and debating the circumstances surrounding his murder. The men's occupation with discussing Sin's potential killers and their motives

5 Except for Quincy "Sin" Soetosenojo, all names are pseudonyms. Some details have been altered to protect participants' identities.

6 Upon comparing field experiences with Roks, Urbanik returned to the field and conducted "problem-centered interviews" (Witzel 2000), specifically focused on how participants experienced and navigated peer fatality.

7 Though 2018 was an unusual year given high-causality events, there was still an increase. 
superseded traditional mourning rituals. Roks was struck by how meticulously the men conducted their pseudo-investigation. Mirroring the methods used by law enforcement officials, they spoke to Sin's friends and acquaintances about whom he had spent time with recently and whether he had any ongoing beefs or problems that they may be unaware of. As both a member of the Crips' chapter in Amsterdam and The Hague, and because he recently joined a Dutch outlaw motorcycle gang, Sin moved in different circles. This prompted the Crips to amass a long list of possible suspects and motives, deploying even the slightest sliver of information to construct suspicions and allegations.

The Crips also collected and fastidiously reviewed eyewitness reports and crime scene photos published by local media to reconstruct Sin's murder and hopefully identify the culprit(s). For example, they drew upon the arrangement of parked cars and the proximity to Sin's home to the crime street to determine that Sin likely knew his killer. The blood stains in the crime scene photos suggested that Sin was walking away from his vehicle when he was ambushed, reaffirming their hypothesis that an acquaintance must have called him over. They also deliberated about eyewitness' media descriptions that the gunfire sounded like 'rattling' to deduce the murder weapon. Crips' founder Raymond was particularly fixated on this, asserting that identifying the gun and bullets could narrow the suspect list and allow them to gauge if other Crips were in danger.

In an environment such as Regent Park, news about homicides and information about suspected shooter(s) and potential motives travels with exceptional velocity. Similar to StudyA, the men dedicated the immediate aftermath after someone was shot (fatally or otherwise) to trying to determine what happened and most importantly, who was responsible. To illustrate, one summer afternoon in 2015, several of Urbanik's participants were playing cards on the boardwalk when they were ambushed by a drive-by shooter. Approximately 30 min later, ${ }^{8}$ Urbanik arrived at the scene to find police had taped off the area, and some of her other participants ${ }^{9}$ and other local residents were already recounting what happened, exchanging intel on the shooter and driver's physical description, analyzing the car's route, and listing recent neighbourhood 'beefs' to determine possible motives, to determine the shooter's identity. ${ }^{10}$ Once they were 'certain' who the shooter was and his motive (less than an hour later $)^{11}$, they called and text others to warn them and to elicit information on his whereabouts.

The speed with which the men in Regent Park conduct pseudo-investigations postshootings and homicides and try to determine the possible culprit(s) even surprised them, as Rehan highlighted: "Pretty quick! So quick, it's crazy- though. Like, even I thought about it a couple times. Like, how did you get this information-that's going down? ... Like, the same day. Like, sometimes before it hits the news, you know?" One afternoon in 2018, a few weeks after a prominent neighbourhood rapper and his affiliate were shot and killed, Matteo-who has lost 12 close friends to gun violence-shared his internal monologue upon learning another loved one was murdered: "Makes you think like, what the fuck? What happened? What did he do? And where the fuck was he going and where did he end up?" Overhearing this, Ezekiel chimed in: "And if it's somebody close, the thought that comes through your head is "Fuck, I could have been with that nigga. That could have been me!" When an affiliate was killed, Urbanik's participants' proximity to the deceased (re)sensitized them to the fact that they may be next. Consequently, meticulously gathering homicide details and any related knowledge is "not for them to solve the crime or anything" — as Asad asserted, but is motivated by a need to uncover what happened which can shape their response (and specifically, retaliation), and can aid in deflecting subsequent victimization. Determining a peer's last moments and more importantly "who you was running with?" is an important survival tactic that can

8 Urbanik was in a local community center when the shooting occurred.

9 Those targeted immediately left the area to stay safe and avoid police interaction.

10 In instances where no eye-witnesses were available, Urbanik's participants had to gather information through other sources, including: social media posts, news media accounts, and details provided by friends and family.

11 While this strategy can result in fatal misunderstandings and errors, it is nevertheless a critical component of neighbourhood life post-shooting. 
help protect members. However, since Urbanik's participants, similar to the Dutch Crips, associated with different groups, identifying the culprit could be challenging.

\section{"Before you know it, you are shaking hands with his killer": Hypervigilance}

In the days following Sin's murder, suspicion and distrust-signs of fear according to van de Port (2001, pp. 109-19)-dominated Crips' conversations. Concerns about whether the killer walks among them even made it to the media; Raymond remarked to a journalist who attended Sin's wake: "Everyone is offering their condolences. Before you know it, you are shaking hands with his killer" (Van Stapele 2012). When Roks spoke to Dre, a younger Crips member, Dre was upset with his comrades for drinking alcohol and criticized their alleged lack of vigilance during such a critical time. Though Dre noted that several officers attended the wake in hopes of gathering intelligence, he nevertheless affirmed his own commitment to protection: "But I had the heat on my balls!", indicating he carried a gun to the wake.

During this time, Roks's participants were in a "hidden state of emergency" (Green 1994, p. 228). Although many members prided themselves on being 'strapped $24 / 7^{\prime}$, they appeared to increase their armament following the murder. Every night that following week, they hid a weapon (e.g., baseball bat, firearm) nearby, something they never did during the previous 20 months of fieldwork. It also seemed like the younger members of the Crips were more vigilant in the h200d, paying extra attention to unknown others. They watched passers-by closely, followed them for several blocks, and sometimes even demanded they remove their hands from their pockets when walking through the neighbourhood.

One week after Sin's death, Raymond summoned almost all the Crips to meet him in the h200d before they travelled together to a nearby forest. Prior to leaving, Raymond demanded they all turn off their cellphones and remove the battery to prevent police monitoring. Once in the forest, the men gathered in a semi-circle with Raymond at the center. He started the meeting with "a moment of silence for the dead homie" and following the reflection, asked the others how they felt. When no one responded, he reiterated the question, which implored the others to respond with: "Angry", "Fucked up", and "It's dark over here, cuzz". Quincy, a younger member and Sin's close friend, expressed his rage and desire to retaliate. Raymond sympathized and admitted he also wanted revenge, though he cautioned that they had to keep their emotions in check until they were certain of the killer's identity. Raymond then recounted the information he gathered during that week and shared his suspicions about who may have more knowledge and who may have been responsible.

A few days after the gathering, Sin was to be buried in Amsterdam. Before the funeral, Raymond asked: "Roks, do you want to come? Just so you know, it is in the middle of enemy territory". The day of the funeral, temperatures were projected to reach over $30^{\circ} \mathrm{C}$. When Roks arrived in the h200d, he met with Marvin, a Crip member since the mid-1990s. After exchanging a quick hug, Marvin asked Roks whether it was obvious he was carrying a gun under his clothes. He pondered whether he should wear his coat, worried that donning a jacket on such a hot day might betray to police or others at the funeral that he was armed. Roks assured him that his oversized T-shirt concealed the gun well, which pleased Marvin. This exchange made him more cognizant of how other Crips dressed for the funeral, and he noted that most wore baggy and oversized clothing, including jackets.

In StudyB, murders initiated an almost identical series of events; news/information travelled quickly, police saturated the neighbourhood, and Urbanik's participants usually retreated indoors to determine what happened, their own risk levels, and whether/how they should respond. See how Leon described the group's reactions upon finding out an affiliate was killed:

"Anger! 'Let's go right now! like where's he [killer] at, who did it?' ... Everything is going through your head, you know? How you lost someone that's really close to you, right? ... There's too much anger, you want to do anything just, you know? So they [killers] can know how you feel the pain, right? And you ain't gonna heal nothing, it's just-you get at them [retaliate]". 
A few days after a young affiliate was shot and killed one summer, Urbanik and another researcher ${ }^{12}$ pulled up to the apartment which served as her participants' home base. The area was eerily quiet which was unusual given its vivacious drug trade. Urbanik text Booker-one of her key participants — that they arrived and he came downstairs with Matteo shortly thereafter. Both men appeared uneasy, looking around frequently, studying passing cars carefully, and staying close to the building entryway-atypical behaviours since they were usually relaxed in that area. When Urbanik asked why it was so deserted, Booker responded: "We're all laying low at Ricky's house. I told em you guys are here, they said they might come down later. Things are hot right now" Urbanik then probed whether it was related to the shooting, he responded: "Yea. This shit got us fucked up. Just trying to figure out whose who and the next play [response], you know? I'd invite ya'll up but trust me-you don't wanna be part of this right now".

Following a peer's murder, Urbanik's participants operated in a state of hypervigilance until they could identify the killer(s) and motive, wary of being outdoors and which group members they spent time with. Matteo described their trepidation upon learning another peer was killed:

"You think you're next. Just cause it's your community that they're dropping close by, right? ... This shit is happening in your backyard. And to find out you don't know who the fuck the killer is? What if I'm chillin' amongst the killer, and he's just planning on the next one? Like, that's what gets me triggered!"

Concerns that the killer may be a close affiliate with intimate knowledge about the men's routines and potentially "planning on the next one" pushed them to withdraw from neighbourhood life and some group members until things settled. Frankie explained why they rarely ventured outdoors until they had had more information: "I'm out numbered, I'm out numbered, I can't come outside ... you don't know who's after who". Once the men narrowed down or identified possible culprits (usually within a week) and eliminated their affiliates from the suspect list, they re-established their neighbourhood presence. However, the possibility of future ambushes meant they usually only ventured outdoors in large groups and only if at least one person was armed in the weeks following a homicide.

Whilst Urbanik's participants considered strength in numbers a safety measure, they acknowledged that they had to remain hyperaware of their surroundings. Booker described the need to be exceptionally cautious following a peer's murder: "You just gotta be on your $P^{\prime} s$ and $Q$ 's more. It makes you paranoid a little bit ... got you looking around more often, over your shoulders. You never know. Anything can be expected, right?" Being on your "Ps and Qs" refers to being "on point", a concept whereby streetwise residents must be hypervigilant, recognizing and mitigating the dangers of their surroundings to thwart violent victimization (Berardi 2018, pp. 120-23). Though Urbanik's participants always had to be circumspect within and beyond Regent Park, peer fatalities amplified their attentiveness in the short term. For example, when discussing one of Urbanik's key participants'-Nathaniel's - murder in 2016, Asther insisted that although he is "always aware" given where he lives and his lifestyle, Nathaniel's murder intensified his wariness: "I'm saying that made me extra cautious, what happened to Nathanial, right?"

When a group member was killed (and especially after the men retaliated), Urbanik's participants were intensely committed to surveilling the neighbourhood to protect residents and themselves from subsequent violence. To illustrate, consider Marcel's response when Urbanik asked how the group's behaviours change when the "hood is hot":

"People would see fishy vehicles, or, fishy people, you know what I mean, and from there, you'd get that sense- like you'd know. We all know everyone from Regent Park. I know everyone who has braids in Regent Park. Someone walks around with braids I don't know? I'll be like 'Look at this guy!' And they would do the same thing ... Altima, tinted, moving funny, driving funny. And we'll just stand on our toes."

12 The researcher was a co-investigator on a separate ongoing study. 
Urbanik's participants deployed other safety protocols during times of heightened risk. For example, they sometimes hung out in full-view of building security cameras in hopes of deterring assailants, rarely veered far from building doors and ensured doors were always open (sometimes breaking locks to ensure a speedy exit), and occasionally avoided funerals/viewings. They also paid residents in easy-access apartments/townhomes to keep their doors unlocked so they could run inside if necessary, increased group communication, and had Urbanik check around adjacent buildings/corners, run neighbourhood errands (e.g., trips to the convenience store), and drive them places. ${ }^{13}$ Similar to Roks's study, peer fatalities in Urbanik's field site sparked a "hidden state of emergency" (Green 1994, p. 228), despite their troubling frequency.

\section{"They trusted someone they shouldn't": Attributing Blame to the Victim}

In comparing StudyA's and StudyB's findings, a third common response to peer murder emerges: how gang members 'make sense of' what occurred. Once the men in the Forgotten Village and in Regent Park identified the probable killer(s), they shifted their attention to the deceased's actions preceding their murder. ${ }^{14}$

While the men in Roks's study mourned Sin, Raymond drew upon the killing to reiterate the informal rules of Dutch gang life:

"That's why I always say: let me know your whereabouts. That shit can keep you alive. Let me know where you are and let me know when you've made it home. I know it sounds childish, but that shit can keep you alive. It's fucked up, but this has to be a lesson for the young homies. This is not a joke, this shit is serious. Fucked up that a homie like Sin has to be the example." (23 August 2012, excerpt from fieldnotes)

This comment offers a window into the daily practices of the Dutch Crips and how they navigate street life. For their own safety, the men were expected to share their whereabouts with other gang members. Raymond maintained that Sin may have prevented his murder if he had adhered to this "code". The ambiguities surrounding Sin's death were obfuscated by depicting Dutch gang life as guided by clear-cut conduct rules. However, instead of seeing this specific 'code' as a concrete determinant of behaviour, the central argument put forth by Copes et al. (2013) is that "telling the code" (Wieder 1974) illustrates how Dutch gang members give meaning to the world around them, explaining their behaviour both to themselves and to others.

Similarly, while the men in Regent Park had mutual concern for each other, they ultimately regarded survival as an individual responsibility:

"It's like, you already know these guys are all talking what they're living ... So, every time I tell them, "Please keep your head up, please. I want to see you tomorrow, stay safe." Everybody. Ask them. They say 'Yeah', but they're not always keeping an eye on their head. "Be safe, be safe." They don't know. Tomorrow's never promised. They be walkin home, getting smoked. It's crazy" (Asad)

"They slipped up, they trusted someone they shouldn't, and guess what? Lights out!" (Jefferson)

In this context, "keeping an eye on their head" refers to "staying on your Ps and Qs," the opposite of being "caught slipping" (see Berardi 2018, pp. 123-37). The men's careful dissection of the deceased's alleged role in their own demise betrays that they perceive and convey gang homicides are preventable, if potential victims operate accordingly. The upshot here is that by being "caught slipping" and not successfully evading victimization (including unprovoked, unanticipated violence), Urbanik's participants regarded being murdered as a choice: "They picked their own poison. They choose to go out [die] when the fuck

13 As a white woman, Urbanik was unlikely to be targeted in the neighbourhood.

14 Though this emphasis was often on the moments immediately before the killing (e.g., who they were with), this could also include earlier actions (e.g., behaviors 'inviting' victimization, like filming a rap video on a rival block). 
they chose to went out. If I told you to do something, and you went and did opposite and you end up dying, I'll feel like, 'fucking dumb mofucker. You should have listened to me'".

Though Booker's reflection appears insensitive, it is rooted in his familiarity with death and victimization as chronic exposure to neighbourhood violence can result in suppression of sadness (see Fowler et al. 2009). When Urbanik asked whether the circumstances surrounding a murder (e.g., wrong place at the wrong time, or provoked retaliation) affected the extent to which the victim was considered responsible for their untimely death, Booker insisted: "You still have to be on the P's and Q's about your own actions, right? So, it doesn't really matter on what they[rivals] did. It's how they[victim] went about it and how they got caught slipping ... you were supposed to be more alert ... " The men also used these expectations to disparage and police others' behaviour, scolding those they believed were too content. Frankie did this often, and he was firm in his position when he described a peer being murdered because of their alleged slip in vigilance: "I' $m$ gonna miss you, yea. You're my boy. But everybody has to use their head. You gotta get up and look, it's like crossing the street ... I don't mind you smoking and taking a nap but get up once in a while and check [for rivals]". Through monitoring and condemning each other's actions, Roks's and Urbanik's participants simultaneously expressed concern for their comrades and propelled expectations that their affiliates were responsible for their own safety. ${ }^{15}$

\section{Residual Effects: The "Realness" and "Reality" of Gang Homicide}

In the previous section, we described commonalities in how gang members reacted to and 'made sense of' peer fatalities. Although the men in both studies adopted similar strategies, our data also reveal notable differences in responses to peer murder. We outline these differences below and document how their varying street milieus produced these differential effects.

\section{"The homie is dead man, please keep it real!": The Transformative Realness of} Sin's murder

One evening about two weeks after Sin's homicide, a couple of Crips members were assigned to conduct "h200d patrol" - where members position themselves around neighbourhood entry points to 'guard' and 'protect' the h200d and senior gang members-from potential enemies (Roks 2017a). Though Sin's death initially heightened caution (sometimes bordering on paranoia), members' hypervigilance and increased safety concerns within the h200d quickly dissipated. For example, when none of the members assigned to h200d patrol reacted when a stranger on a scooter passed a pedestrian-only area, the gang leader, annoyed by h200d patrol's disregard, scoffed: "The homie is dead man, please keep it real!" In this case, "keeping it real" referred to representing and defending Crips' 'turf.' This 'strip of reality' (Appadurai 1996, p. 35) - since many gangs engage in defensive localism (Adamson 2000) - forms a base 'out of which scripts can be formed of imagined lives'. However, the transformative realness of Sin's murder produced different interpretative schemes. From the perspective of the gang leader and more established members-including longterm associates since the late 1980s-claiming a hood and defending their territory is something 'real gangstas' do (Lauger 2012), particularly in the aftermath of peer fatality. However, this was incongruent with how younger and new Crips perceived Sin's murder and 'the need for' h200d patrol. Since nothing 'went down' in the weeks after Sin's death, this signaled that the h200d was losing its 'hood' status and had become an unexciting place. For these members, Sin's murder did not reaffirm the 'realness' of Dutch gang life but planted doubts about the function and necessity of defending a hood.

In his pioneering work on gangs, Thrasher [1927] (Thrasher [1927] 1964, p. 46) posits conflicts with invisible or imagined adversaries can aid in gang integration: an "integration through conflict". After Sin's death, a similar process occurred as the event amplified several intra-group conflicts, mostly relating to a growing disillusion with Dutch gang

15 This was particularly true given broad distrust in police and perceptions of their ineffectiveness, with many participants attempting to protect themselves in a milieu of police racism, brutality, and corruption. 
life. Starting some months before Sin's murder, the gang's composition changed drastically; several previously-dedicated Crips lost interest in the group and left and younger members were increasingly frustrated about their inadequate compensation for their work for the Crips, which they saw as outweighing benefits of gang membership (Roks 2017b). Dwindling membership dominated conversations, almost always against the backdrop of Sin's murder. Rick, one of the OGs, spoke for many of the older members when he made sense of the Crips' waning:

"After Sin was killed, the shit became too real for them. Then they couldn't bang anymore, because they suddenly had a job or something. But you know, the police also knows this. That's why they see us as the core members. But many have left, man." (20 December 2012, conversation with Rick)

Sin's murder was a defining moment that impacted all Crips, albeit in different ways. For example, while older members claimed that they had lost close friends to violence before and a few even asserted they "were used to it", others openly shared that they cried frequently and had trouble sleeping since the homicide. For some members, Sin's murder revealed who and what was "real". In this sense, Sin's death had a "transformative magic" that brought "comic-book symbolism" to life (Katz 1988, pp. 129-31; Van Hellemont 2015, pp. 191-224), (re)affirming the "realness" of the Rollin 200 Crips. For others however, the murder ignited or cemented growing doubts about the reality-or realness - of belonging to a Dutch gang. Members who left reported being drawn to the gang because of their violent representations and street reputation; they had certain ideas about the realness of Dutch gang life, in part inspired by media accounts of the Dutch Crips and influenced by stereotypical representation of American gang life in movies, documentaries, and YouTube (rap) videos. For them, beliefs about the realness of Dutch gang life were shattered by the day-to-day realities, which usually consisted of spending long hours in the h200d doing nothing.

Sin's murder also had a transcendental significance for the Rollin 200 Crips. Annually, multiple social media accounts dedicate posts to commemorating Sin. For example, on the website of a recently established outlaw motorcycle gang that features prominent Dutch Crips members (Roks and Densley 2020), a page is devoted to all the "cuzzos that we lost over the years", which maintains "They will never be forgotten". The caption beneath Sin's picture reads "Triad in Peace Sin Locc". These digital artifacts transmute Sin's well-respected status within the gang and simultaneously, as Conquergood (1994, pp. 51-52) analysis of physical death murals for gang members attests, are "a generative source of strengthening cohesion and commitment" and activate the group's "cultural memory". In addition to these memorials, several Crip members have named their children (boys and girls) after Sin. Through these communicative and mythmaking practices, the Dutch Crips have woven Sin's murder into their gang mythology.

\section{"Out here everyone thinks they're next": The Reality of Gang Homicide in Re- gent Park}

Similar to others living in impoverished communities characterized by stigmatization, limited services, and neighbourhood violence (see Aspholm 2020, p. 217), peer murder was an unfortunate lived reality for Urbanik's participants and all considered it unavoidable. However, while the men were heavily traumatized by losing their first peer to gun violence (usually at 10-12 years old) they all reported becoming accustomed to affiliate murder, referring to it as "normal", "an everyday thing" and "just a part of life". The normalcy and near predictability of peer murder meant that even when Urbanik's participants sat around 'doing nothing' like the men in The Forgotten Village, they needed to remain vigilant and always be prepared to defend themselves, their crews, and their turf. Unlike Roks's participants who experienced peer fatality as signifying or demystifying the 'realness' of gang life, the materiality and 'realness' of gang life in Regent Park was never in question. Instead, Urbanik's participants conveyed that the troubling routineness of peer fatality both accustomed and benumbed them to losing loved ones. Booker succinctly described 
this desensitization: "You just get over it [the murder] much faster now than before ... You lost people, after people, after people. It becomes like, you know, a common thing. When you get used to something, it's not as bad as the first time, right?" As Asther reflected upon his best friend's murder one afternoon, Urbanik asked whether subsequent losses affected him similarly. He responded: "No, they don't. Cause like, since that happened, it's like [snaps fingers to denote frequency] you get used to it ... it's easier for me this time". Claims about becoming habituated to murder are consistent with literature which has found youth exposed to community violence may become emotionally desensitized to it as a form of pathological adaptation and/or a coping mechanism (See Fowler et al. 2009 for a review).

This desensitization also meant that the 'effects' of peer homicide on group behaviours often abated quickly:

"Like [when] someone dies, like yesterday, yeah-we all mourning them. Just give it like a week later, people probably forget and people be all happy, laughing and doing their own thing. But when it happens again, we're back mourning them, then back to our normal life. We lose so much people that it just, it's like an everyday thing." (Leon)

Similarly, Stefano described that while the group is "Edgy for a couple of days" after a member's homicide they "Have to get back to life... This is not the 1st time- this is not gonna be the last time. It's not the 3rd time, it's the 100th time". These descriptions align with Urbanik's field observations. While the men spent the initial weeks post-murder openly mourning their loved ones and being hypervigilant, these behaviours largely dwindled thereafter. This was not because Urbanik's participants were unaffected by their peer's passing or questioned the 'realness' of gang life (like Roks's participants). They continued to commemorate them, engaging in several memorial processes including "pouring some out for the dead homies,"16 producing commemoratory rap videos, and honouring them on social media (Urbanik Forthcoming). However, they believed they had to "get back to life" and "cool off" for survival; they needed to decompress quickly in anticipation of and preparation for subsequent murders and/or their own potential victimization.

Though the frequency of peer homicides necessitated that Urbanik's participants "get over" peer fatality quickly, their tragic regularity shaped group dynamics, creating a communal and perpetual state of insecurity. This insecurity manifest itself via pervasive beliefs members could be killed at any moment, eroding group cohesion, and (re)inciting distrust among members. Unlike Roks's participants who questioned the need to defend their turf after Sin's murder, Urbanik's participants maintained that letting their guard down even momentarily could be fatal and resigned themselves to the possibility they could be murdered next. See Leon's proclamation, for example: "It could happen anytime. It could happen to us, you know? Me, just personally like, I just take it-it could happen to me at any time, it could happen to anybody, right?" Marcel held a similar opinion, adding nuance based on the neighbourhood's ongoing revitalization which rendered violence less predictable and avoidable (see also Urbanik et al. 2017: "At the end of the day, out here everyone thinks they're next, that's what it is. It's like, the fucking way they breaking the shit down, bodies are dropping. The more buildings go down, the more bodies".

Since neighbourhood violence was always imminent, Urbanik's participants insisted that even when the neighbourhood is "quiet" and hyperawareness is unnecessary they must remain cautious and behave accordingly. As Ezekiel stressed: "You gotta play your cards right. Life is a gamble, and they say it for a reason. You gotta roll the dice the right way". Yet, Ezekiel contradicted himself immediately: "You could just walk the street, look at someone wrong, and they just shoot you. What part of the game is that? That's not-that's crazy". Here, a tension exists between the alleged safety provided by "playing your cards right" —not being "caught slipping" - where one's decisions can allegedly dictate survival or death, and life as a "gamble", where playing by street rules does not always shield against victimization. These perspectives are incongruent; on the one hand victimization is ascribed to individual

16 A ritual of pouring alcohol out of freshly opened bottles on to the ground whilst reciting the names of murdered friends in a show of respect. 
failures and on the other, it is credited to fatalism. This paradox likely reflects the men's attempts at feigning control in an environment where they have little (and sometimes zero) control over safety.

The nature and frequency of peer fatality in Regent Park also bred distrust between group members. While recounting his best friend's murder several years earlier, Matteo elucidated how this loss shattered his trust and reliance in his peers: "Don't trust nobody. Cause it was his own people that he trust that killed him. And no one knows that I know [culprit's identity]. I don't trust a soul, I don't bring no one to where I live. I rest my head [relax] nowhere. I learned to distance ... from the bullshit. I ain't trying to go[die] like that". Despite Matteo's recognition of these dangers and proclamation of pervasive distrust, he-like Urbanik's other participants—saw few possibilities of distancing "from the bullshit" and disengaging from 'the life.' He remains a staple of Regent Park's underground economy, spends his days with other members, features in rap music videos, and engages in "hood politics". Unlike Roks's participants who could and did disengage from gang life, Urbanik's participants' different street milieus and positionalities limited their ability to do the same. As such, they continued to navigate their increasingly distrustful and tumultuous relationships with group members, spending time together and operating as a cohesive unit all whilst remaining suspicious of each other:

"He was on a block- that was supposed to be allies ... He thought he was ok, you know?

The same allies hit him up [killed him]. So, you know ... As much as people might be your allies, you still can't trust them, right?" (Leon)

Having lost many peers to gun violence and having been set up and shot, Leon was chronically wary of his "allies," explaining how this eroded his trust in other group members: "I know how to move now. I watch my surroundings. I don't chill with no one, I only chill with who you see I'm here with every day. That's it. I don't need no new friends. Friends will get you killed, they say ... " In Toronto's street milieu, "the violent threat and militaristic response exist in the same social circle" (Katz 1988, p. 218).

Many of Urbanik's participants adhered to the "friends will get you killed" mantra, echoing similar sentiments: "The streets talk. So, when you hear what happened, learn how not to move, basically, you know? Usually the best way to stay is by yourself, to yourself. Don't have anyone watching your moves and stuff" (Booker). The men went to great lengths to prevent even trusted peers from studying their habits. They kept unpredictable schedules, seldom shared their whereabouts, and rarely committed to being at a specific place at a specific time in fear that other members may set them up (see also Goffman 2015). In this sense, 'everyday' community violence coupled with less common but still too frequent gang homicides produced and exacerbated chronic suspicion of group members, undermined reliance on group protection, and propelled additional violence (see also Winton 2005). However, this disassociation did not push the men to become disillusioned with "the life" like Roks's participants, though they certainly questioned their peers' loyalty, by and large, they did not consider 'leaving the life', in part because they believed they had few alternatives.

\section{Discussion}

In this paper, we explored how gang members make sense of peer murder(s) and the residual effects of these violent events for gang members and their respective groups. Despite the nuances in our respective studies, our data reveal notable commonalities in how gang-involved men in two distinct contexts experience and respond to peer fatalities. In both The Forgotten Village and Regent Park, gang-involved men initiate pseudo-murder investigations, become hypervigilant in the immediate aftermath, and attribute blame to the victim in attempts to 'make sense' of the violence. Below, we describe additional commonalities in the how gang homicides affected our participants and their communities.

First, our data reveal that gang-involved men experience loss in complex, multidimensional ways. For the men in our respective studies, grief was a personal and communal 
experience which produced individualized and collective effects, including trauma. ${ }^{17}$ Drawing attention to gang members' lived experiences-particularly in relation to their exposure to traumatic events, such as peer fatalities-is critical given societal and media narratives which often pathologize gang members, portraying them as callous criminals. Whilst our participants were offenders, they were also victims with extensive histories of violent victimization by family members, friends, strangers, and rivals, usually commencing long before they were old enough to join "the life". Apart from their own victimization, the men also experienced vicarious victimization and trauma. The common unilateral focus on gang members as offenders obfuscates their experiences as simultaneously victims, dehumanizes them, masks their structural oppression, and de-contextualizes their decisions and behaviours. As Pyrooz et al. (2014, p. 321) highlight: "This disjuncture has done a disservice to criminology in general and gang research in particular for understanding the linkages between these concepts".

Second, gang homicides in both studies had immense collateral consequences that extended beyond victims, perpetrators, and other gang members, deeply impacting families, loved ones, and communities. As evidenced, peer homicides had the potential to (e.g., in The Forgotten Village) or did (e.g., in Regent Park) drive the cycle of victimization, affecting inter-gang relations, retaliatory violence, and community safety. As such, gang murders continue past the homicide; they can propel and are propelled by social contagion, organizational memory, networks of competing groups jockeying for power, status, and resources, which shape future gang behaviours, including homicide (Papachristos 2009, p. 76). Future research should examine these collateral consequences in greater depth.

Third, how gang members made sense of, experienced, and responded to peer fatality was intimately shaped by the specific street, social, economic, and political contexts in which they were situated. Both of our studies involved marginalized and predominantly racialized men socially excluded and 'othered' in their respective societies (albeit to varying degrees), including in the education system and labor market, because of race and socioeconomic status. They were also - again, to varying degrees-harmed by and had to navigate state violence most notably in the form of criminalization, overpolicing, and police racism. For our participants, gang membership and its related activities (e.g., violence, drugs and weapons trafficking, other criminal endeavors) was a form of "resistant identity" (Castells 1997), a situated response and adaptation to their marginalization. Similar to other marginalized, gang-involved men, our participants reported that gang membership afforded them with opportunities that they felt were less or unavailable elsewhere, including economic benefits, independence, a sense of belonging, a (group) identity, and masculinity.

Fourth, in both studies, social media was central to how participants processed and responded to peer fatality. Though a thorough examination of how the "digital street" (Lane 2015, 2018) affects gang homicides is beyond the scope of this paper, our participants relied upon social media to learn about others' victimization, anticipate and hopefully evade future violence, collect information on potential motives/suspects, determine rivals' locations/movements, commemorate and grieve their murdered affiliates, try to save face when disrespected, and threaten to avenge their loved ones' homicide(s). Though much of their online presentations were performative and sometimes departed from real life (see Roks 2017b; Stuart 2020; Van Hellemont 2012), Urbanik's participants engaged in digital bravado, sometimes provoking suspected murderers and starting beefs with rivals and had to simultaneously navigate the risks and dangers of doing so (Urbanik and Haggerty 2018; Urbanik Forthcoming), which Roks's participants did not. Though social media can incite and propel gang violence in the real world, it is unclear which digital interactions can produce offline violence (Stuart 2020) and how the street and online milieus in which gangs' operate can affect this. Future research should examine the extent to which social media affects on-the-ground processes, including inter- and intra-gang dynamics.

17 Whilst our participants spoke of how traumatic peer homicide is, they likely understated these effects given normative expectations about masculinity and gang narratives emphasizing toughness. 
Despite these commonalities, the men in The Forgotten Village and in Regent Park had vastly different lived realities. While both our studies were based upon studying marginalized and street-involved men, the types and extent of our participants' marginalization differed, in part, due to their varying street contexts and positionality within their respective societies. We posit that these differences shaped how the men perceived, experienced, and responded to peer homicide. As our data reveal, Dutch Crips members opted into gang life because of glamorized ideals about what gang life entailed and opted out and pursued alternate avenues (e.g., collecting unemployment benefits, finding regular, low-paying jobs, or resorting back to street offending) when they became disillusioned (Roks 2017b). Notably, feasible alternatives existed and could be pursued. Gang joining and gang exit were distinct processes with few consequences, as violent victimization was rare even for the most senior members and whilst they claimed membership provided them protection, the broader social milieu rendered this alleged protection was largely unnecessary. By leaving the gang, they could essentially escape risk.

Conversely, gang life was not something the men in Regent Park consciously opted into or could essentially opt out of. Almost of all Urbanik's participants were born or fell into 'the life' because of their upbringing and neighbourhood context. The men reported Old Heads-often brothers, cousins, fathers, uncles, neighbours-grooming them into gang-related activities (e.g., drug running, stashing weapons, monitoring for police) during their pre-teen years, and merely "going along with it" as they aged. As poor and racialized men living in "the ghetto," they saw few if any opportunities to support themselves and their families outside of the informal economy, especially as they accrued lengthier criminal records. Since most were unable to relocate, gang exit seemed both implausible and futile as they could not easily sever their social ties and they considered violent victimization largely inescapable. ${ }^{18}$

Our findings also uncover that variances in our participants' respective positionalities and street cultures produced differences in how they experienced peer murder. In accordance with Mares (2010, p. 41) observation that "the circumstances and settings of gang violence are highly variable", our findings indicate that the street milieus in which gang violence and homicide occur can have a notable influence on how gang member's experience and respond to peer fatality. In Roks's field site, gang violence and especially murder, was rare and momentous. One peer homicide prompted members' to contemplate the realness of Dutch gang life. Contrary to StudyA, the tragic frequency of peer fatalities in Regent Park diluted their impacts as murders did not have a "transformative magic" (Katz 1988, p.129). Homicides did not signal the realness of gang life in Regent Park; the frequency of peer murder and the incessant risks posed by merely living in Regent Park meant these risks were largely imparted, inescapable, and had to be carefully mitigated. Though additional deaths were unquestioningly tragic, their effects were relatively shortlived as the men recognized the need to "move on" quickly in preparation for the next loss.

While peer homicide disintegrated group trust and amplified conflict in both field sites, this occurred to varying degrees and in different contexts and therefore had different consequences for gang dynamics. In Roks's study, Sin's murder played a notable role in creating and exacerbating existing intra-gang disagreements and temporarily brewed distrust between group members. These mounting tensions pushed some members to leave the gang. Peer fatalities in Regent Park had similar effects, though they were amplified, particularly in terms of mounting distrust in and fear of trusted affiliates. Unlike in StudyA, this chronic wariness did not push the men to consider leaving gang life, as they were already navigating an environment where gang violence and broad distrust was the

18 For many Black men/youth in Regent Park, "staying out of the life" does not necessarily protect them from violent victimization. 
norm. ${ }^{19}$ Whilst peer fatalities amplified distrust in the short-term, homicides did not notably change the gang's fabric, as they did in StudyA.

Like other social realities and motivations for action, gang violence is often influenced by an intersecting multiplicity of factors, and should be examined as a cultural, psychosocial, behavioural, and transactional manifestation occurring in a particular social setting (Brotherton 2015, p. 163) with locally-specific consequences. As our data show, while similarly disadvantaged gang-involved men in different gang, street, local, and national contexts make sense of, experience, and respond to peer fatality similarly, their experiences differ in notable ways due to their divergent social, economic, and political milieus. As such, examinations of how affiliate murders affect gang members and gang dynamics should be carefully situated within the broader milieus in which gang members operate. Going forward, gang scholars should remain cognizant of the complexity and messiness of gang violence and how its local context affects experiences of gang homicides.

Author Contributions: Conceptualization, M.-M.U. and R.A.R.; methodology, M.-M.U. and R.A.R.; formal analysis, M.-M.U. and R.A.R.; investigation, M.-M.U. and R.A.R.; writing-original draft preparation, M.-M.U. and R.A.R.; writing - review and editing, M.-M.U. and R.A.R. All authors have read and agreed to the published version of the manuscript.

Funding: This work was partly supported by the Netherlands Organisation for Scientific Research (NWO) under the program 'Conflict and Security' (grant no. 432-08-089 to R.R.) and party supported by Social Sciences and Humanities Research Council of Canada (grant number 767-2015-1881).

Institutional Review Board Statement: Urbanik's study received Research Ethics Board Approval from the University of Alberta (Pro00052729). Roks' study did not require REB approval

Informed Consent Statement: Informed consent was obtained from all subjects involved in the study.

Data Availability Statement: Data is contained within the article.

Conflicts of Interest: The authors declare no conflict of interest.

\section{References}

Adams, Jennifer J., and Jesenia M. Pizarro. 2014. Patterns of specialization and escalation in the criminal careers of gang and non-gang homicide offenders. Criminal Justice and Behavior 41: 237-55. [CrossRef]

Adamson, Christopher. 2000. 'Defensive localism in white and black: A comparative history of European-American and AfricanAmerican youth gangs'. Ethnic and Racial Studies 23: 272-98. [CrossRef]

Aldridge, Judith, Robert Ralphs, and Juanjo Medina. 2011. Collateral damage: Territory and policing in an English gang city. In Youth in Crisis. Edited by Barry Goldson. New York: Routledge, pp. 72-88.

Anderson, Elijah. 1999. Code of the Street: Decency, Violence, and the Moral Life of the Inner City. New York: W.W. Norton and Co.

Appadurai, Arjun. 1996. Modernity at Large: Cultural dimensions of Globalization. Minneapolis: University of Minnesota Press.

Aspholm, Roberto. 2020. Views from the Streets: The Transformation of Gangs and Violence on Chicago's South Side. New York: Columbia University Press.

Berardi, Luca. 2018. 'Shots Fired: Experiences of Gun Violence and Victimization in Toronto Social Housing'. Ph.D. dissertation, University of Alberta, Edmonton, AB, Canada.

Blumstein, Alfred. 1995. Youth violence, guns, and the illicit-drug industry. The Journal of Criminal law and Criminology 86: 10-36. [CrossRef]

Brotherton, David C. 2015. Youth Street Gangs: A Critical Appraisal. New York: Routledge.

Brotherton, David C., and Luis Barrios. 2004. The Almighty Latin King and Queen Nation. New York: Columbia University Press.

Bursik, Robert, and Harold G. Grasmick. 1993. Economic deprivation and neighborhood crime rates, 1960-1980. Law E Society Review 27: 263-84.

Castells, Manuel. 1997. The Power of Identity. Oxford: Black-Well.

CBS. 2017. More Murder and Manslaughter Victims in 2017. Available online: https://www.cbs.nl/en-gb/news/2018/36/moremurder-and-manslaughter-victims-in-2017, (accessed on 9 January 2021).

CBS. 2020. Number of Homicides Halved over Two Decades. Available online: https://www.cbs.nl/en-gb/news/2020/42/numberof-homicides-halved-over-two-decades, (accessed on 9 January 2021).

19 Their distrust must also be understood in relation to their broader distrust across their lives, and particularly, in broader social institutions which have often served as a source of institutional violence (see also Goffman 2015). 
Conquergood, Dwight. 1994. Homeboys and Hoods: Gang Communication and Cultural Space. In Groups Communication in Context: Studies of Natural Groups. Edited by Larry R. Frey. Hillsdale: Lawrence Erlbaum Associates, pp. 23-55.

Copes, Heith, Brookman Fiona, and Anastasia Brown. 2013. Accounting for violations of the convict code. Deviant Behavior 34: 841-58. [CrossRef]

Curry, G. David, and Irving A. Spergel. 1988. Gang Homicide, Delinquency, and Community. Criminology 26: 381-407. [CrossRef]

Curtis, Ric. 2003. Crack, cocaine and heroin: Drug eras in Williamsburg, Brooklyn, 1960-2000. Addiction Research E Theory 11: 47-63.

Decker, Scott H. 1996. Collective and Normative Features of Gang Violence. Justice Quarterly 13: 243-64. [CrossRef]

Decker, Scott H., and G. David Curry. 2002. Gangs, Gang Homicide, and Gang Loyalty. Journal of Criminal Justice 30: 343-52. [CrossRef]

Decker, Scott H., and David C. Pyrooz. 2010. On the validity and reliability of gang homicide. Homicide Studies 14: 359-76. [CrossRef]

Decker, Scott H., and David C. Pyrooz. 2013. "Gangs: Another Form of Organized Crime?". In Oxford Handbook of Organized Crime. Edited by Letizia Paoli. New York: Oxford University Press, pp. 270-87.

Densley, James A. 2012. Street gang recruitment: Signaling, screening, and selection. Social Problems 59: 301-21.

Densley, James A. 2014. It's gang life, but not as we know it: The evolution of gang business. Crime E Delinquency 60: 517-46.

Esbensen, Finn Aage, Thomas Winfree Jr., Ni He, and Terrance J. Taylor. 2001. Youth gangs and definitional issues. Crime and Delinquency 47: 105-30. [CrossRef]

Fine, Gary. A. 2010. The sociology of the local: Action and its publics. Sociological Theory 28: 356-76. [CrossRef]

Fowler, Patrick J., Carolyn J. Tompsett, Jordan M. Braciszewski, Angela J. Jacques-Tiura, and Boris B. Baltes. 2009. Community violence: A meta-analysis on the effect of exposure and mental health outcomes of children and adolescents. Development and Psychopathology 21: 227-59. [CrossRef] [PubMed]

Ganpat, Soenita M., and Marieke C. A. Liem. 2012. Homicide in the Netherlands. In Handbook of European Homicide Research. Edited by Marieke C. A. Liem and William Alex Pridemore. New York: Springer, pp. 329-41.

Geertz, Clifford. 1998. Deep hanging out. New York Review of Books 45: 69-72.

Global News. 2019. Toronto Police Chief Says Recent String of Gun Violence in City Related to Street Gangs. August 9. Available online: https:/ / globalnews.ca/news/5746070/toronto-police-chief-mark-saunders-gun-violence/ (accessed on 9 October 2020).

Goffman, Alice. 2015. On the Run: Fugitive Life in an American City. Chicago: University of Chicago Press.

Green, Linda. 1994. Fear as a Way of Life. Cultural Anthropology 9: 227-56. [CrossRef]

Hagedorn, John M. 1994. Neighborhoods, markets, and gang drug organization. Journal of Research in Crime and Delinquency 31: 264-94. [CrossRef]

Hagedorn, John M., and Perry Macon. 1988. People and Folks: Gangs, Crime and the Underclass in a Rustbelt city. Chicago: Lake View Press.

Howell, James C. 1999. Youth gang homicides: A literature review. Crime and Delinquency 45: 208-41. [CrossRef]

Jacobs, Bruce A., and Richard Wright. 2006. Street Justice: Retaliation in the Criminal Underworld. New York: Cambridge University Press.

Katz, Jack. 1988. The Seductions of Crime. New York: Basic Books.

Klein, Malcolm W. 2005. The Value of Comparisons in Street Gang Research. Journal of Contemporary Criminal Justice 21: 135-52. [CrossRef]

Klein, Malcolm. W., and Cheryl L. Maxson. 1989. Street Gang Violence. In Violent Crime, Violent Criminals. Edited by Neil Alan Weiner and Marvin E. Wolfgang. Newbury Park: Sage.

Klein, Malcolm, Frank Weerman, and Terrance Thornberry. 2006. "Street gang violence in Europe". European Journal of Criminology 3: 413-437. [CrossRef]

Kubrin, Charis E., and Tim Wadsworth. 2003. Identifying the Structural Correlates of African-American Killings. Homicide Studies 7: 3-35. [CrossRef]

Kubrin, Charis E., and Ronald Weitzer. 2003. Retaliatory homicide: Concentrated Disadvantage and Neighborhood Culture. Social Problems 50: 157-80. [CrossRef]

Lane, Jeffrey. 2015. The digital street. American Behavioral Scientist 60: 43-58. [CrossRef]

Lane, Jeffrey. 2018. The Digital Street. New York: Oxford University.

Lauger, Timothy R. 2012. Real Gangstas: Legitimacy, Reputation, and Violence in the Intergang Environment. New Brunswick: Rutgers University Press.

Lewis, Kevin, and Andrew V. Papachristos. 2020. Rules of the game: Exponential random graph models of a gang homicide network. Social Forces 98: 1829-58. [CrossRef]

Mares, Dennis. 2010. Social Disorganization and Gang Homicides in Chicago. Youth Violence and Juvenile Justice 8: 38-57. [CrossRef]

Maxson, Cheryl L. 1999. Gang Homicide: A Review and Extension of the Literature. In Homicide: A Sourcebook of Social Research. Edited by M. Dwayne Smith and Margaret A. Zahn. Thousand Oaks: Sage, pp. 239-56.

Maxson, Cheryl L., and Malcolm. W. Klein. 1990. Street gang violence: Twice as great, or half as great? In Gangs in America. Edited by C. Ronald Huff. Thousand Oaks: SAGE, pp. 71-100.

Maxson, Cheryl L., and Malcolm. W. Klein. 1996. Defining gang homicide. In Gangs in America, 2nd ed. Edited by C. Ronald Huff. Thousand Oaks: SAGE, pp. 3-20.

Maxson, Cheryl L., Margaret A. Gordon, and Malcolm W. Klein. 1985. Differences between Gang and Nongang Homicides. Criminology 23: 209-12. [CrossRef] 
Miethe, Terance D., and Richard C. McCorkle. 2002. Evaluating Nevada's antigang legislation and gang prosecution units. In Responding to Gangs: Evaluation and Research; Edited by Winifred L. Reed and Scott H. Decker. Washington, DC: National Institute of Justice, pp. 169-85.

Miller, Walter B. 1975. Violence by Youth Gangs and Youth Gangs as Crime Problem in Major American Cities; Washington, DC: SGPO, Office of Juvenile Justice and Delinquency Prevention, U.S. Department of Justice.

Papachristos, Andrew V. 2009. Murder by Structure: Dominance Relations and the Social Structure of Gang Homicide. American Journal of Sociology 115: 74-128. [CrossRef]

Papachristos, Andrew V., and David S. Kirk. 2006. Neighborhood Effects on Street Gang Behavior. In Studying Youth Gangs. Edited by James F. Short and Lorine Hughes. Lanham: Altamira, pp. 63-85.

Papachristos, Andrew V., David Hureau, and Anthony Braga. 2013. The corner and the crew. American Sociological Review 78: 417-47. [CrossRef]

Pizarro, Jesenia M., and Jean Marie McGloin. 2006. Explaining gang homicides in Newark, New Jersey. Journal of Criminal Justice 34: 195-207. [CrossRef]

Pyrooz, David C. 2012. Structural covariates of gang homicide in large U.S. cities. Journal of Research in Crime and Delinquency 49: 489-518. [CrossRef]

Pyrooz, David C., Scott E. Wolfe, and Cassia Spohn. 2011. Gang-related homicide charging decisions: The implementation of specialized prosecution unit in Los Angeles. Criminal Justice Policy Review 22: 3-26. [CrossRef]

Pyrooz, David C., Richard K. Moule, and Scott H. Decker. 2014. The contribution of gang membership to the victim-offender overlap. Journal of Research in Crime and Delinquency 51: 315-48. [CrossRef]

Rodgers, D. 2002. We Live in a State of Siege: Violence, Crime, and Gangs in Post-Conflict Urban Nicaragua. DESTIN Working Paper No. 36. London: Development Studies Institute (DESTIN), London School of Economics.

Roks, Robert A. 2017a. "Crip or die? Gang disengagement in the Netherlands". Journal of Contemporary Ethnography. [CrossRef] [PubMed]

Roks, Robert A. 2017b. "In the 'h200d': Crips and the intersection between space and identity in the Netherlands". Crime, Media, Culture. [CrossRef]

Roks, Robert A., and James A. Densley. 2020. From Breakers to Bikers: The Evolution of the Dutch Crips 'Gang'. Deviant Behavior 41: 525-42. [CrossRef]

Rosenfeld, Richard, Timothy M. Bray, and Arlen Egley. 1999. Facilitating Violence: A Comparison of Gang-Motivated, Gang-Affiliated, and Non-Gang Youth Homicides. Journal of Quantitative Criminology 15: 495-516. [CrossRef]

RTL Nieuws. 2020. Toename vuurwapengeweld in Nederland: vorig jaar 646 incidenten. Available online: https://www.rtlnieuws.nl/ nieuws/nederland/artikel/5095871/vuurwapen-wapens-illegaal-criminelen-toename-politie-2019-2018 (accessed on 9 January 2021).

Skarbek, David. 2011. Governance and prison gangs. American Political Science Review 105: 702-16. [CrossRef]

Skogan, Wesley. 1974. The Validity of Official Crime Statistics. Social Science Quarterly 55: 25-38.

Spergel, Irving A. 1984. Violent Gangs in Chicago. Social Service Review 5: 199-226. [CrossRef]

Statistics Canada. 2019. Homicide in Canada. 2018. Available online: https://www150.statcan.gc.ca/n1/pub/85-002-x/2019001/ article/00016-eng.htm (accessed on 4 October 2020).

Stuart, Forrest. 2020. Ballad of the Bullet: Gangs, Drill Music, and the Power of Online Infamy. Princeton: Princeton University Press.

Thrasher, Frederic M. 1964. The Gang. Chicago: University of Chicago Press. First published 1927.

Urbanik, Marta-Marika. 2018. Drawing Boundaries or Drawing Weapons? Neighborhood Master Status as Suppressor of Gang Violence. Qualitative Sociology 41: 497-519. [CrossRef]

Urbanik, Marta-Marika, and Kevin D. Haggerty. 2018. '\#It's Dangerous': The Online World of Drug Dealers, Rappers and the Street Code. The British Journal of Criminology 58: 1343-60.

Urbanik, Marta-Marika, and Robert A. Roks. 2020. GangstaLife: Fusing Urban Ethnography with Netnography in Gang Studies. Qualitative Sociology 43: 213-33. [CrossRef]

Urbanik, Marta-Marika, Sara K. Thompson, and Sandra M. Bucerius. 2017. 'Before There Was Danger but There Was Rules and Safety in Those Rules': Effects of Neighbourhood Redevelopment on Criminal Structures. The British Journal of Criminology 57: 422-40. [CrossRef]

Urbanik, Marta-Marika, Roks Robert A, Storrod Michelle, and Densley James. 2020. "Emerging Issues in Gang Ethnography: The Challenges and Opportunities of Eurogang Research in a Digital Age". In Gangs in the Era of Internet and Social Media. Edited by Chris Melde and Frank Weerman. New York: Springer.

Urbanik, Marta-Marika. “Gangbangers are Gangbangers, Hustlers are Hustlers”: The Rap Game, Social Media, and Gang Violence in Toronto. In International Handbook of Critical Gang Studies. Edited by David Brotherton and Rafael Gude. London: Routledge, Forthcoming.

van de Port, Mattijs. 2001. Geliquideerd: Criminele Afrekeningen in Nederland. Amsterdam: Meulenhoff.

Van der Valk, Joost. 2009. Strapped ' $n$ Strong. Available online: https://revolver.nl/film-tv/2120/crips-strapped-n-strong (accessed on 9 January 2021).

Van Hellemont, Elke. 2012. Gangland Online: Performing the Real Imaginary World of Gangstas and Ghettos in Brussels. European Journal of Crime, Criminal Law and Criminal Justice 20: 159-73. [CrossRef] 
Van Hellemont, Elke. 2015. The Gang Game: The Myth and Seduction of Gangs. Ph.D. dissertation, Koninklijke Universiteit van Leuven, Leuven, Belgium.

Van Stapele, Saul. 2012. 'Deze Crip sliep al jaren “heel lichtjes"'. NRC Handelsblad, August 21.

Vargas, Robert. 2014. Criminal group embeddedness and the adverse effects of arresting a gang's leader. Criminology 52: 143-68. [CrossRef]

Viering, Peter. 1994. Straatroof, inbraak, doodslag [Street Robbery, Burglary, and Manslaughter]. Panorama 3: 37-42.

Warmington, Joe. 2020. Wild Weekend of Shootings Like a Civil War. Toronto Sun. September 28. Available online: https: // torontosun.com/news/local-news/warmington-wild-weekend-of-shootings-like-a-civil-war (accessed on 3 October 2020).

Wieder, D. Lawrence. 1974. Language and Social Reality: The Case of Telling the Convict Code. Den Haag: Mouton.

Winton, Ailsa. 2005. Youth, gangs and violence: Analysing the social and spatial mobility of young people in Guate mala City. Children's Geographies 3: 167-84. [CrossRef]

Witzel, Andreas. 2000. The Problem-centered Interview. Forum: Qualitative Social Research 1: 1-7. 